\title{
"Mais do que nunca é preciso cantar": o papel dos musicais do Grupo Opinião na construção da resistência democrática (1964-1966)
}

Mariana Rodrigues Rosell

\section{Resumo:}

Este artigo pretende refletir sobre a importância que os espetáculos musicais do Grupo Opinião tiveram no processo de construção da resistência democrática ao regime militar brasileiro, vigente após o golpe civil-militar de I964. A política aliancista de resistência esteve na base do projeto estético e ideológico de um dos principais nomes da resistência cultural ao regime militar brasileiro, o Grupo Opinião, e se manifestou já em seus primeiros espetáculos: Opinião (I964) e Liberdade, liberdade (I965). Ambos formularam uma espécie de modelo para a resistência pautada pelo frentismo cultural e são bons exemplos das características que nortearam a atuação de grandes nomes da dramaturgia brasileira, como Oduvaldo Vianna Filho e Paulo Pontes, que estiveram no Opinião desde sua fundação até o primeiro racha interno do grupo, em I967. Palavras-chave: Grupo Opinião - Teatro Brasileiro - Regime Militar - Resistência Cultural 
"Mais do que nunca é preciso cantar"

$\mathrm{Na}$ orelha que escreveu para o livro História, teatro e política, organizado por Kátia Paranhos, Francisco Alambert afirma que o

Teatro é História, ou é a história em ato. A história é teatro, ou só pode ser entendida e narrada nesses termos. Por isso é sempre fundamental que os historiadores e cientistas sociais vejam o teatro como seu objeto. E isso ainda é raro (PARANHOS 2012, orelha).

O historiador aponta a relevância de enxergar o teatro enquanto fonte histórica na medida em que funciona como um importante registro de seu período, ao mesmo tempo em que destaca a ausência de trabalhos historiográficos que tenham o teatro como principal objeto de pesquisa. Durante o regime militar brasileiro, essa área da cultura foi um dos primeiros e principais espaços de resistência, devendo então ser visto como um documento privilegiado desse momento histórico. Este artigo pretende colaborar para o preenchimento de parte dessa lacuna historiográfica que recai sobre o teatro e pensar a história do teatro político brasileiro e o teatro da história do regime militar.

\section{Teatro brasileiro: renovação, politização e resistência}

Nos anos que antecederam o regime militar, o teatro brasileiro viveu uma importante renovação, que tocou seus âmbitos estético, político-ideológico e dramático, e marcou a trajetória da grande maioria dos artistas cujos nomes estão gravados na história da cultura brasileira. Essa renovação foi inspirada por questionamentos feitos por esses artistas, que estiveram envolvidos nas atividades teatrais durante este período cuja análise é fundamental para a compreensão do papel que as artes desempenhariam na resistência aos militares.

O golpe de I964 interrompeu o desenvolvimento de projetos político- culturais que surgiram a partir dessa renovação - norteados pela concepção nacional-popular, ${ }^{\mathrm{I}}$ buscavam articular arte e povo, cultura e política;

I A ideia de nacional-popular aqui referida pode ser resumidamente caracterizada pelos projetos artístico-culturais que buscaram trabalhar numa linguagem comum às diferentes classes sociais, a partir da articulação de referências da cultura popular nacional e da cultura erudita universal. 
sua interrupção obrigou os artistas que tentavam colocá-los em prática a se reorganizarem sob a sombra da repressão e da censura e com a necessidade de inserirem em suas propostas uma nova questão: a luta contra o regime recém-implantado.

Nesse contexto de reestruturação das artes, o teatro foi a primeira área a organizar uma resposta aos militares, já apontando o destaque que as artes teriam na resistência democrática ao governo autoritário. Tal destaque se deu, sobretudo, durante os primeiros anos do regime, quando os artistas tiveram relativa liberdade de atuação. Fernando Peixoto, integrante do Teatro Oficina, afirma que "de I964 a I968 fizemos o teatro de resistência, de protesto, mas o AI-5 foi o princípio do fim de todos nós" (BADER I987, p. 233).

Para uma melhor compreensão deste artigo, é preciso esclarecer desde o início que a resistência ao regime militar se deu em diversas frentes e de formas diferentes. Em determinados momentos, muito em função do descontentamento com o regime e algumas de suas práticas - como a violenta repressão -, divergências políticas foram momentaneamente deixadas de lado a fim de um posicionamento amplo contra o autoritarismo do governo militar. Isso, contudo, não apaga as diferentes propostas de resistência feitas ao longo dos 2I anos de regime autoritário.

A revisão historiográfica dos últimos anos vem cotejando essas formas de atuação e apontando como a oposição aos militares se configurou. No tocante ao assunto que aqui nos cabe estudar, uma importante referência é a tese de livre-docência de Napolitano, que discute, justamente, a atuação da sociedade nesse contexto. Ele aponta que, na área cultural, é possível identificar quatro grupos distintos: comunistas, liberais, contracultura e nova esquerda (NAPOLITANO 2OII). Isto posto, passemos à atuação dos resistentes no campo teatral.

Nessa área especificamente ocorreu uma organização de oposição relativamente rápida e efetiva, que resultou no show Opinião, apresentado ainda em dezembro de 1964 pelo grupo que, mais tarde, se tornaria seu homônimo e um dos principais nomes da resistência cultural ao regime militar. Sobre isso, ainda em sua tese de livre-docência, Marcos Napolitano corrobora o pioneirismo do teatro na resistência ao regime, sobretudo no que ele chama de "primeira fase da resistência cultural" (id. ibid., p. 62). Assim, é fundamental analisar o teatro e seu papel crucial nessa atuação, para que se tenha uma compreensão mais consistente da resistência ao regime militar em sua chave artístico-cultural.

Assim como outros grupos teatrais do período, o Opinião receberia a influência dos estudos brechtianos, tendo como peculiaridade o tom aliancista, 
"Mais do que nunca é preciso cantar"

que aqui será analisado a partir de seus dois primeiros espetáculos. O teatro épico chegou ao Brasil no final da década de 1950 , com a primeira encenação de um texto de Bertolt Brecht, A alma boa de Setsuan, pelo grupo Teatro Popular de Arte em São Paulo (BADER I987, p. 224). Fernando Peixoto, no entanto, no texto supracitado, entende que "Brecht nos chega, enquanto companheiro de trabalho, [somente] nos anos I960" (id. ibid., p. 239).

Esse período de efervescência cultural e política foi caracterizado pelo gênero épico, ${ }^{2}$ sobretudo em virtude de sua perspectiva de análise da sociedade e de sua apresentação como resultado de um processo histórico, diferenciando-se assim do teatro dramático. ${ }^{3}$ Por tratar das questões do tecido social, priorizando o ponto de vista das classes em relação às questões individuais e elaborando a construção de uma análise crítica, o gênero épico se adequava ao projeto de teatro que visava a discussão, a atuação política e a transformação da sociedade. No Dicionário do teatro brasileiro, a colaboradora Rosângela Patriota afirma que

foi no âmbito do teatro engajado que o épico esteve presente de maneira mais sistemática [nos palcos brasileiros]. A aproximação com os escritos teóricos e com a dramaturgia de BRECHT inspirou dramaturgos como Oduvaldo VIANNA FILHO, Augusto BOAL, Gianfrancesco GUARNIERI, Carlos Queiroz TELLES, entre outros (GUINSBURG et al. 2009, p. I43).

No livro organizado por Wolfgang Bader, Brecht no Brasil: experiências e influências, o crítico de teatro Sábato Magaldi afirma: "Acredito que a influência mais importante de Brecht [...] se refira, num momento decisivo de nossa trajetória cultural, à consciência política por ele impressa no teatro brasileiro" (BADER I987, p. 225). No mesmo livro, o também crítico Yan Michalski dialoga com essa visão:

2 Por teatro épico, entendemos aquele formulado pelo dramaturgo alemão Erwin Piscator que, "movido pelo compromisso histórico de transformação social, formulou a teoria e uma nova prática do teatro épico, construindo espetáculos sobre diferentes planos históricos", e vinculado ao teatro político por outro importante dramaturgo alemão, Bertolt Brecht (GUINSBURG et al. 2009, p. I42).

3 O teatro dramático é aquele "que sugere que o espectador é cativado pela ação. [...] é a dramaturgia clássica, do realismo e do naturalismo [...]: se tornou a forma canônica do teatro ocidental desde a célebre definição de tragédia pela Poética de Aristóteles" (PAVIS 20II, p. IIO). É caracterizado, entre outros elementos, pela conquista do público, que desenvolve certa empatia com as personagens, o que acaba por dificultar a análise crítica das temáticas encenadas. 
a maior contribuição de Brecht para o nosso teatro nem sequer são suas peças que vimos em cena, e sim sua visão de mundo, [...] sua visão do mundo, dos homens, da organização social e, por que não, do teatro, [...] influenciou decisiva e muito positivamente as cabeças da minha geração e da geração que se seguiu [...] (id. ibid., pp. 228-29).

Podemos perceber então que, mais do que através de seus textos teatrais ou que teorizam sobre o gênero épico, Brecht se constituiu numa das principais influências dos artistas do teatro brasileiro pela sua forma de enxergar a relação entre arte e política, a função do teatro enquanto agente de transformação social e a própria sociedade em que estavam todos inseridos. Sua visão de mundo, portanto, indubitavelmente contribuiu para a organização do teatro político brasileiro, pouco antes e, especialmente, depois do golpe de I964.

Com o Grupo Opinião não foi diferente. Além de Yan Michalski, que aponta referências e influências em "vários espetáculos do [Grupo] Opinião" (id. ibid., p. 23I), João das Neves, um de seus fundadores, afirma que "este grupo aprofundou um tipo de dramaturgia e de encenação que, se não tinha Brecht como ponto de partida, deve, no entanto, à sua reflexão muito da qualidade alcançada" (id. ibid., p. 242). Ou seja, mesmo sem nunca ter encenado uma peça escrita por Brecht, ${ }^{4}$ a concepção brechtiana da sociedade, da arte e suas funções, enfim, sua visão de mundo, esteve muito presente na atuação do grupo e, mais amplamente, de todo o teatro político brasileiro.

Este artigo pretende mostrar o papel do frentismo cultural na construção da resistência ao regime militar através da análise de um dos seus principais nomes, o Grupo Opinião, formado apenas cerca de oito meses após o golpe por artistas que, em sua maioria, eram remanescentes do Centro Popular de Cultura da União Nacional dos Estudantes (CPG-UNE), posto na ilegalidade assim que o governo de João Goulart foi deposto. Para isso, nos centramos na observação de seus dois primeiros espetáculos - Opinião (I964) e Liberdade, liberdade (I965) - que, assemelhados também pela forma estética que articulava texto e canção, devem ao seu pioneirismo a condição de modelo de resistência cultural.

4 Lembremos, no entanto, que em Liberdade liberdade é citado um trecho da peça Terror e miséria do III Reich, de Bertolt Brecht (FERNANDES; RANGEL ig65, pp. I20-28). 
"Mais do que nunca é preciso cantar"

\section{Grupo Opinião: resistência de base aliancista}

Como já foi apontado neste artigo, a resistência ao regime militar se deu de diferentes e divergentes maneiras, delineadas de acordo com o projeto de país que se tinha e também com o método pelo qual se acreditava ser o melhor para atingi-lo. Também nesse sentido é preciso refletir sobre as diferentes reações que o golpe provocou na sociedade, visto que elas estão diretamente relacionadas às formas de resistência posteriores a ele.

Parte da ala liberal (no caso, sobretudo políticos e atuantes da imprensa) não só apoiou o golpe como também clamou por ele nos dias que o antecederam, sentindo-se ameaçada pelo governo de João Goulart, encabeçado pelas propostas das reformas de base. ${ }^{5}$ Esses agentes liberais entenderam que um golpe era a melhor forma de prevenir mudanças possivelmente transformadoras do status quo que lhes assegurava os privilégios de classe. Mas, ao perceberem que os militares buscavam cada vez mais institucionalizar o regime recém-implantado, ao contrário do que imaginavam ter chancelado, aos poucos, os liberais romperiam com eles. ${ }^{6}$ A esquerda se veria mais fragmentada, uma vez que com o recrudescimento do autoritarismo e da repressão, as dissidências do Partido Comunista Brasileiro (PCB) que propunham a intervenção armada como melhor forma de resistência seriam cada vez mais numerosas.

5 As chamadas reformas de base eram, basicamente, cinco: universitária, fiscal, bancária, administrativa e, a principal delas, agrária. Acabaram por constituir-se na bandeira principal do governo de João Goulart e foram usadas como uma das principais justificativas para o golpe civil-militar, na medida em que, para a visão da direita, eram a "antessala da revolução comunista".

6 Um bom exemplo é o posicionamento do jornal Correio da Manhã, do Rio de Janeiro, cujos dois editorias "Basta!" (3I mar. I964) e "Basta! e Fora!" (O2 abr. I964) ficaram famosos por demonstrarem bem como a imprensa liberal se posicionou acerca do governo João Goulart e logo após o golpe. No editorial do dia 3I de março, lê-se: "Os Poderes Legislativo e Judiciário, as classes armadas, as forças democráticas devem estar alertas e vigilantes e prontos para combater todos aqueles que atentem contra o regime. O Brasil já sofreu demasiado com o governo atual, agora basta!" Já no do dia 2 de abril, o editorial diz: "Está terminado o episódio mais inglório da história republicana do Brasil. Basta! Mas não só basta disso, também basta de aproveitamento reacionário do episódio. Basta! e Fora! Não combatemos a ilegalidade para alterar com outra ilegalidade. A reação já comete crimes piores que os cometidos. Depõe Governadores, prende Ministros e Deputados, incendeia prédios, persegue sob a desculpa de anticomunismo a tudo e a todos. Não admitiremos; a estes fanáticos e reacionários opomos a mesma atitude firme de ontem. A eles também diremos: Basta! e Fora!”. Os editoriais completos estão disponíveis no acervo da Hemeroteca Digital da Fundação Biblioteca Nacional: <http://memoria.bn.br>. Acesso em: 20 fev. 2014 . 
A partir de então se configuram no período aqui estudado, grosso modo, duas linhas de atuação para as esquerdas: I) resistência democrática, com opção pela luta política, defendida pelo PGB em sua Resolução de Maio de $1965 ;{ }^{7}$ 2) luta armada, defendendo a formação de núcleos de guerrilha urbana e rural, posta em prática por várias organizações, tais como Ação Libertadora Nacional (ALN) - liderada por Carlos Marighella - e Vanguarda Popular Revolucionária (VPR) - depois, VAR-Palmares, cujo grande nome é Carlos Lamarca. O PCB definiu a resistência democrática como principal linha de atuação do partido e teve no teatro, durante todo o regime, um grande - talvez o maior - espaço de difusão dessa concepção, pautada no frentismo cultural.

O golpe representou um entrave ao projeto político-cultural nacional- popular, provocando uma mudança no público dos artistas que buscavam interagir com as classes populares, como aqueles vinculados ao GPG-UNE, por exemplo. Assim, seu público passava das pessoas nas ruas, nas portas de fábricas e nas periferias para a classe média pagante. Nesse novo contexto se formou o Grupo Opinião, nascido durante o processo de criação do show homônimo, que estrearia em finais de 1964 e seria a primeira resposta artística ao golpe que havia sido perpetrado meses antes. É a esse contexto, portanto, que o grupo e suas peças tentam responder utilizando para isso diversos recursos estéticos e artísticos, cujos melhores exemplos são os espetáculos que articulavam o texto a um repertório musical. Os dois principais representantes desta forma são objetos de estudo deste artigo: Opinião (I964) e Liberdade, liberdade (I965).

O Grupo Opinião, definido como "Grupo carioca que centraliza, nos anos I960, o teatro de protesto e de resistência" (ENGICLOPÉDIA... 20IO), é um dos principais núcleos de produção artística no período aqui abordado e, por isso, permite uma melhor compreensão do teatro de protesto e do contexto específico em que ele norteou a resistência aos governos militares.

O Opinião enquanto "grupo de teatro preocupado com a discussão dos problemas nacionais" deixaria de existir no final da década de I960 (GAR-

7 A resolução do comitê central do $\mathrm{PGB}$, resultado da primeira reunião realizada pelo partido após o golpe, reiterou o que já havia sido definido em I958, quando optou-se definitivamente, entre outras coisas, pela aliança de classes, entendida como necessária num país de terceiro mundo. Ou seja, a partir dessa opção, a fragmentação do PGB se intensificou, determinando o rompimento com aqueles que discordavam dessas determinações, os dissidentes. Entre eles, lideranças históricas do partido, como Carlos Marighella e Joaquim Câmara Ferreira, que teriam importante atuação na luta armada. 
"Mais do que nunca é preciso cantar"

CIA 20II, p. I7I.), e o ano de I967 marca o rompimento de seu primeiro ciclo. Após divergências internas, dois de seus principais nomes, Oduvaldo Vianna Filho e Paulo Pontes, que estiveram com o grupo desde sua fundação, o deixam para fundar o Teatro do Autor. ${ }^{8} \mathrm{O}$ momento principal do Grupo Opinião como foco de resistência se dá exatamente nesses primeiros anos que antecederam o AI-5. Entre I964 e I966, ao lado do Teatro de Arena de São Paulo, ele concentrou o papel da resistência ao regime militar no campo teatral.

Por isso este artigo tem como enfoque a análise dessas duas peças que, por terem sido concebidas e encenadas entre I964 e I966, concentram as características centrais do Opinião, que marcariam a história do grupo, do teatro brasileiro e do papel deste na resistência ao regime militar. Essas características são as seguintes: mescla de referências, apelo tanto popular como de elite e a base aliancista de seu projeto; e todas foram favorecidas pela relação entre o texto e o repertório musical, cuidadosamente elaborado para essas duas peças.

Mais do que todos os outros grupos que assim como ele tiveram atuação de destaque no contexto da resistência ao regime militar, o Opinião tornou-se um porta-voz do projeto político do Partido Comunista Brasileiro (PGB), ${ }^{9}$ que, pautado pela concepção etapista, propunha a aliança de classes como meio para vencer o arcaísmo e realizar a primeira etapa da revolução brasileira: a revolução burguesa. Este projeto esteve na base da proposta estético-ideológica do grupo, sobretudo nos seus primeiros anos (I964-I968), quando houve certa liberdade de atuação para a classe artística. ${ }^{\text {Io }}$

8 Ambos os dramaturgos escreveriam importantes peças na primeira metade da década de I970, que se tornariam paradigmas da retomada dos palcos brasileiros pelos dramaturgos comunistas. Rasga coração (I974) e Gota d'água (I975) são, até hoje, reconhecidas como grandes obras que sintetizam inúmeras questões das esquerdas e do povo brasileiro durante o regime militar.

9 Talvez esse papel central do teatro na manifestação do projeto político do PCB na cultura - e, talvez mais além, na construção de uma política cultural baseada nos pressupostos do partido - esteja relacionado à ligação de grandes nomes do teatro político brasileiro, desde o início, ao PCB. Maria Silvia Betti aponta que "O TPE [Teatro Paulista do Estudante] foi fundado em abril de I955, dentro da militância estudantil do Partido Comunista Brasileiro, por iniciativa de um grupo de amadores ligados à União da Juventude Comunista e composto [entre outros] por Oduvaldo Vianna Filho [...] e Gianfrancesco Guarnieri [...]. O grupo não tinha, em sua origem, um programa cultural definido, mas seus integrantes haviam elegido o teatro como instrumento de uma tarefa partidária autoassumida, sem o objetivo de profissionalização teatral” (FARIA 20I3, p. I76).

Io Sobre isso, vale atentar ao apontamento feito por Maria Silvia Betti, que diz "o que parece indiscutível é que a ideia da frente democrática [...] passaria a servir de base a todo o movimento de resistência constituído no teatro brasileiro no período que vai de 1964 até a decretação do Ato Institucional número 5, em I968" (FARIA 20I3, p. I97). 


\section{Opinião e Liberdade, liberdade: cantando a resistência}

Passaremos agora à análise dos dois espetáculos cujas características estéticas, ideológicas e políticas apontam para a conformação da resistência democrática ao regime militar. Opinião e Liberdade, liberdade foram os dois primeiros espetáculos do Grupo Opinião e, como já foi apontado, apresentam alguns elementos centrais em comum. Em termos formais há, além da conjugação de textos e canções, o uso do palco de arena; o diálogo entre os atores - que se referem entre si pelo próprio nome, constituindo-se, assim, em atores-personagem; o recurso à colagem de excertos de textos, aos quais se somavam trechos escritos especialmente para os espetáculos; ${ }^{\mathrm{II}}$ a ironia e as matrizes diversas que fornecem os materiais para a elaboração dos textos. Em termos de conteúdo, podemos apontar o norte ideológico marcado pelo engajamento na construção de uma frente ampla de resistência e a temática relacionada ao nacional-popular - presente, sobretudo, no repertório musical.

Outras semelhanças também se fazem notar: a colaboração do elenco (e, mais amplamente, do conjunto de pessoas que trabalhou nos espetáculos) na elaboração da peça a partir de uma determinada concepção; o sucesso imediato de ambos os espetáculos; a edição em livro dos textos completos, acompanhados de registros iconográficos e depoimentos; o lançamento em LP do registro parcial do áudio das apresentações. Há ainda outros pontos em comum, que serão apontados ao longo das análises para uma melhor compreensão de seu conteúdo.

Sobre o recurso à canção popular, Roberto Schwarz faz uma consideração interessante: para ele, em Opinião e Liberdade, liberdade, esta integração colaboraria para um melhor desempenho de público, em virtude de uma relação especial, afetiva, que os brasileiros têm com a música popular. Ele diz:

Neste enredo, a música resultava principalmente como resumo, autêntico, de uma experiência social, como a opinião que todo cidadão tem o direito de formar e cantar, mesmo que a ditadura não queira. Idetificavam-se assim para efeito ideológico a música popular - que é com o futebol a manifestação chegada ao

II O recurso da colagem, apesar de já bastante difundido em outros países, como os Estados Unidos, ainda era de uso pouco comum no Brasil, e é também uma aproximação com o gênero épico, na medida em que permite uma quebra na ação dramática que, por sua vez, favorece a reflexão crítica sobre o que se encena. 
"Mais do que nunca é preciso cantar"

coração do brasileiro - e a democracia, o povo e a autenticidade, contra o regime dos militares. [...] o mesmo esquema liberal [de Opinião], de resistência à ditadura, servia a outro grande sucesso, Liberdade, liberdade (SCHWARZ I978, p. 80).

É preciso considerar, contudo, que essa forma inovadora no teatro brasileiro, responsável por grandes sucessos de público e crítica e modelar para a atuação da frente de resistência cultural, conviveu com os impasses e dilemas que se apresentavam à esquerda engajada mesmo antes do golpe de I964, mas que se intensificaram num país sob um regime autoritário e promotor de uma modernização capitalista conservadora que reproduziu e intensificou as desigualdades sociais. Os projetos de popularização da cultura - tanto no acesso como na concepção e na produção - foram boicotados pelos militares de várias maneiras, entre elas, o brusco e imediato rompimento do elo entre artistas e intelectuais com as classes populares.

\section{I. Opinião (1964)}

O show Opinião foi escrito por Oduvaldo Vianna Filho, Paulo Pontes e Armando Costa. No entanto, é importante destacar que as participações tanto do elenco (Nara Leão, Zé Keti e João do Vale) quanto do diretor, Augusto Boal, foram notadamente relevantes para a concepção do espetáculo tal como foi aos palcos. ${ }^{12} \mathrm{O}$ nome, inspirado no samba homônimo de Zé Keti, pouco depois nomearia também o grupo que o elaborou. O espetáculo estreou ainda em I964, no dia II de dezembro, no teatro de arena do Shopping Center de Copacabana, Rio de Janeiro, e se constituiu na primeira resposta ao golpe militar. Tal condição é apontada e corroborada por pesquisadores de diferentes áreas. ${ }^{13}$

Com uma forma que articulava dramaturgia e música, texto e canção popular, Opinião se tornou um enorme sucesso de público e teve suas canções, durante muito tempo, entre as mais tocadas nas rádios. Era o primeiro espetáculo desse grupo, que já aqui trazia as bases da política aliancista na resistência ao regime militar. Miliandre Garcia diz que:

I2 A colaboração dos três cantores-atores é central, na medida em que o texto foi elaborado a partir dos depoimentos dados por eles.

I3 Gf. BETTI. In: FARIA 2OI3, v. II; GRAVO ALBIN 2003; DINIZ 2006; HOLLANDA; GONÇALVES I982; MOSTAÇO I982; NAPOLITANO 200I e 2OII; NEVES I987, v. 5; SGHWARZ I978. 
Sob inspiração da "frente única", os músicos escolhidos como protagonistas do espetáculo representavam estratos progressistas do povo brasileiro que deveriam lutar pela libertação do país que se encontrava sob jugo dos militares e da dominação norte-americana e, portanto, colocava-se como entrave à transformação da realidade brasileira (GARCIA 20II, p. I7I).

Dirigido por Augusto Boal, nome do Teatro de Arena de São Paulo, ${ }^{14}$ teve como protagonistas Nara Leão, João do Vale e Zé Keti, que representavam a si mesmos e, consequentemente, cada um dos estratos sociais que deveriam se aliar nessa frente ampla de resistência ao regime militar. Nara Leão, então musa da Bossa Nova, representava a classe média nacionalista, a burguesia engajada; João do Vale falava em nome dos migrantes nordestinos; e Zé Keti trazia ao palco as gentes do morro carioca, das periferias do país. ${ }^{15}$ Tal elaboração facilitava o diálogo entre palco e plateia na medida em que esta estava representada pela figura de Nara Leão, a despeito da divisão entre os dois espaços estar ainda bastante definida como bem relembra o próprio Augusto Boal em suas memórias (BOAL 2000). ${ }^{16}$

Toda a concepção do espetáculo esteve pautada na proposta aliancista de resistência, que deveria abarcar amplamente todos aqueles que pretendessem combater e derrubar os militares através da luta política e nos "limites da legalidade”. Tal qual a orientação do Partido Comunista Brasileiro de I958, que seria ainda reafirmada na sua Resolução de Maio de I965. ${ }^{17}$ Em Cultura e participação nos anos 6o, Heloísa Buarque de Hollanda e Marcos Augusto Gonçalves

I4 Desde a derrubada do presidente João Goulart pelo golpe civil-militar, a União Nacional dos Estudantes (UNE) havia sido posta na ilegalidade. Essa condição se estendeu ao Gentro Popular de Cultura (CPC), relacionado à entidade estudantil. Em razão disso, os elaboradores do show Opinião, por motivo de sua ligação com o GPG, evitaram ao máximo ter seus nomes vinculados ao espetáculo. A escolha de Augusto Boal como diretor e do Teatro de Arena de São Paulo como produtor funcionaram como meio de manter a participação de antigos membros do CPC discreta.

I5 Já em janeiro de 1965, pouco depois de um mês da estreia do espetáculo, Nara Leão precisaria ser substituída em função de um problema nas cordas vocais. Primeiro por Suzana de Moraes e, posteriormente, por Maria Bethânia. Tais fatos provocaram algumas modificações tanto no texto - já que ele também era composto por depoimentos pessoais dos atores - como nessa organização de representação de estratos sociais. No entanto, cabe aqui analisar o espetáculo da forma como foi originalmente concebido: com uma moça representante da classe média da zona sul do Rio de Janeiro.

I6 No prefácio à edição do texto do espetáculo em livro, os três autores afirmam "Nara Leão não pretende cantar para o público. Pretende interpretar o público." (COSTA; PONTES; VIANNA FILHO, I965, p. 8) Ou seja, Nara Leão é a representante do público, é aquela que os traz ao palco enquanto classe.

I7 Para a leitura completa da Resolução do Comitê Central do PGB de I965, cf. CARONE, I982, pp. I5-26. 
"Mais do que nunca é preciso cantar"

apontam que o espetáculo trazia em si alguns resquícios do projeto ligado ao nacional-popular de articulação entre arte e política e entre intelectuais e povo, que foi interrompido pelo golpe. Ao mesmo tempo, Opinião já era uma tentativa de resposta a essa nova conjuntura, marcada pelo autoritarismo, pela censura e pela repressão (HOLLANDA; GONÇALVES I982). Já Maria Silvia Betti afirma que

A ideia de uma ampla e estratégica frente de oposição e resistência indicava uma grande afinidade entre o pensamento político implícito no Show e as posições do Partido Comunista Brasileiro, ao qual se ligavam, formal ou informalmente, importantes expoentes do contexto intelectual e artístico do país naquele momento (FARIA 20I3, p. I96).

No começo do espetáculo os três cantores-atores se apresentam, em depoimentos que resumem suas trajetórias de vida. As diferenças entre as experiências de vida de cada um, sobretudo de Nara Leão em relação a Zé Kéti e João do Vale, denotam que estão ali pessoas pertencentes a diferentes classes sociais e, ao mesmo tempo, aponta para a aliança progressista que se projeta. Aliança essa que deve cativar e trazer o público para o projeto aliancista de resistência, ${ }^{18}$ embora aqui esteja posto um limite de abrangência, na medida em que este público era composto quase que exclusivamente pela classe média intelectualizada e estudantil-universitária, sendo necessária outra forma para que se chegasse ao público povo, representado por Zé Kéti e João do Vale. ${ }^{19}$

\section{II. Liberdade, liberdade (1965)}

Em I965, o então Grupo Opinião traria à cena o espetáculo Liberdade, liberdade, que seguiria uma linha bastante similar a de seu antecessor. Novamente arti-

I8 Maria Silvia Betti diz que "O papel desempenhado pelo público de classe média logo após o golpe também teve peso considerável nesse processo por ter demonstrado, desde a estreia de Opinião, total apoio à ideia de uma resistência simbolicamente enunciada por uma frente de esquerda e em pleno âmbito do teatro comercial" (FARIA 20I3, p. I96)

I9 Edelcio Mostaço vai concentrar aqui sua principal crítica ao modelo de espetáculo do Opinião, considerando que este acabava por constituir um circuito fechado de comunicação, de quem sabe para quem já sabe (MOSTAÇO I982, p. 8I). 
culando textos a canções, este segundo espetáculo do grupo se tornaria, também em pouco tempo, outro grande sucesso de público. Excursionando por várias capitais e trazendo, desde o nome, mais uma tentativa de responder ao regime militar, Liberdade, liberdade passaria à história como o primeiro espetáculo do teatro de protesto e merece destaque por ter aliado comprometimento político e qualidade estética (GARGIA 20II, p. I75).

Escrito por Millôr Fernandes e Flávio Rangel - que também a dirigiu -, este espetáculo contaria novamente com a participação de Nara Leão, dessa vez ao lado de Oduvaldo Vianna Filho, Teresa Rachel e Paulo Autran. Mais uma vez um texto montado a partir da técnica da colagem de excertos e pensado em colaboração com o elenco. Estreou no mesmo teatro do Shopping Center de Copacabana, em 2I de abril de I965, data que retoma Tiradentes, considerado um mártir da liberdade.

À parte as tantas semelhanças já apontadas, Liberdade, liberdade tem algo de bastante diferente do show Opinião: enquanto neste se propõe uma aliança entre classes, a aliança que se propõe naquele é intraclasse; trata-se de uma aliança entre burgueses, porém de orientações políticas diferentes. Em Opinião se canta a aliança entre o povo, as classes populares, e a burguesia nacional progressista; em Liberdade, liberdade canta-se a aliança entre a classe média engajada, de esquerda, e a classe média liberal, cada vez mais descontente com o regime imposto pelo golpe que, majoritariamente, havia apoiado. Os dois espetáculos, portanto, funcionam, pode-se dizer, como complementares, uma vez que as duas propostas deveriam se configurar numa só aliança, numa frente ampla de resistência, com destaque para a sua atuação cultural.

Assim, nota-se que a composição do elenco não traz representantes das classes populares, mas sim quatro membros da classe média, sendo que Nara Leão e Oduvaldo Vianna Filho - cada um com seu grau de militância ${ }^{20}$ representavam a esquerda engajada, e Paulo Autran e Teresa Rachel, representavam a classe média dita "apolítica", ${ }^{21}$ mas, ainda assim, aproximada

20 Com grau de militância, se quer apontar as diferentes trajetórias políticas de Nara Leão e Oduvaldo Vianna Filho: enquanto a primeira aos poucos passava da condição de musa da Bossa Nova à de grande intérprete de canções de protesto (diga-se, muito em função de sua atuação no show Opinião), o segundo tinha já uma longa e aprofundada militância de esquerda, marcada pelo alinhamento ao projeto político do Partido Comunista Brasileiro.

2 I Em uma entrevista ao programa Roda Viva, em 2002, Paulo Autran lembraria sua participação em Liberdade, liberdade e destacaria a importância que esse trabalho teve para politizá-lo e para despertar-lhe a consciência de que ser ou se considerar apolítico é também uma posição política. O vídeo está disponível em <http://www.youtube.com/watch?v=2Ype44mJo3U〉. Acesso em 27 fev. 2014. 
"Mais do que nunca é preciso cantar"

da posição liberal. O mesmo se nota com os dois diretores do espetáculo: Millôr Fernandes e Flávio Rangel; o último se engajava paulatinamente, distanciando-se de sua origem ligada ao Teatro Brasileiro de Comédia (TBC), e o primeiro sempre com uma posição crítica, mas não necessariamente alinhada ao PGB.

Outro fator bastante sintomático do tom aliancista deste espetáculo é o conjunto de reações que se seguiram a sua estreia. Ambos os extremos, à esquerda e à direita, manifestaram sua insatisfação diante da proposição do segundo espetáculo musical do Grupo Opinião. À esquerda, as críticas se concentraram sobre o fato de o texto conter uma referência direta ao julgamento do poeta Joseph Brodsky pelo regime soviético a cinco anos de trabalhos forçados por parasitismo social. À direita, muitas foram as razões de críticas publicadas, em sua maioria, na imprensa -, que podem ser sintetizadas na acusação de se tratar de uma peça que retrata a falta de liberdade somente sob os regimes de direita, ignorando que os regimes socialistas ou comunistas, como Cuba, China e URSS, dela também careciam. ${ }^{22}$

Retomemos agora o princípio da comparação entre as duas peças de modo que possamos apontar uma similaridade de conteúdo expressa em dois trechos bastante centrais para a mensagem de ambos os espetáculos. Em Opinião, destaco o momento em que todos cantam a canção "Opinião", de autoria de Zé Kéti; em Liberdade, liberdade, a cena em que Paulo Autran declama o julgamento de Sócrates. Nos dois momentos, o que se apreende é que a despeito da violência sofrida pelo indivíduo, a ideia proclamada, a opinião defendida e sus tentada é maior e permanece viva. Assim, mesmo com a repressão desmedida não se finda a crença em seu ideal ou a resistência contra o regime ilegítimo e autoritário: "Podem me prender/ Podem me bater/ Podem, até deixar-me sem comer/ Que eu não mudo de opinião" (COSTA; PONTES; VIANNA FILHO i965, p. 62). Nem mesmo a morte, no caso de Sócrates, faz com que seu legado seja esquecido: "Não podeis me ferir, porque não podeis me atingir. Podeis apenas matar-me, exilar-me, ou cassar meus direitos políticos. Mas eu não sou o primeiro; e não há perigo que eu seja o último" (FERNANDES; RANGEL I965, p. I3, grifo nosso).

Por fim, uma última similaridade de conteúdo: a presença em ambos os espetáculos da canção "Marcha da quarta-feira de cinzas", de autoria de

22 Para uma análise mais aprofundada do espetáculo Liberdade, liberdade e dos artistas envolvidos com ele, cf. ROSELL 20I3, pp. 23I-54. 
Carlos Lyra e Vinicius de Moraes, que sintetiza a visão do Grupo Opinião (e de um setor mais amplo da esquerda) a respeito da situação vivida e da resistência que se construía, pautada pelo frentismo cultural, no qual a música popular e o teatro engajado, muitas vezes aliado a ela, desempenharam papel fundamental e para a qual formularam uma espécie de modelo, como defende Edélcio Mostaço: ${ }^{23}$

E no entanto é preciso cantar/ Mais que nunca é preciso cantar/É preciso cantar e alegrar a cidade// A tristeza que a gente tem/ Qualquer dia vai se acabar/ Todos vão sorrir/Voltou a esperança/ É o povo que dança/ Contente da vida/ Feliz a cantar (FERNANDES; RANGEL ig65, p. 2).

Essa canção sintetiza metaforicamente, mas não só, o projeto de resistência cultural aliancista, na medida em que reivindica a necessidade de se cantar, mais do que nunca, diante da "tristeza" que se vive, pois, assim, "todos vão sorrir". Todos esses elementos apontados neste artigo caracterizam esses dois espetáculos e acabaram por influir nas manifestações pautadas no frentismo cultural, principalmente, em virtude de sua condição pioneira e quase imediata de posicionamento político diante do regime militar. Também a estrutura formal de Opinião e Liberdade, liberdade seria utilizada em muitos outros espetáculos nos anos seguintes (KÜHNER; ROCHA 200I, p. 42). Além disso, por muitos anos - até hoje, talvez - os artistas envolvidos em sua produção e/ou execução teriam seu nome vinculado a eles e a eles atribuiriam importantes mudanças de pensamento, posicionamento político e carreira artística.

Opinião e Liberdade, liberdade, indiscutivelmente, são fundamentais para a compreensão desse momento tão complexo da história do Brasil recente; não só pelo que representaram em si, mas também e, sobretudo, por terem se tornado espetáculos paradigmáticos para uma via de resistência que representou grandes porções da intelectualidade brasileira e, intencionalmente ou não, refletiu e deu voz ao projeto político do Partido Comunista Brasileiro, que, mesmo na ilegalidade, foi um dos principais agentes políticos durante o regime militar.

23 O estudioso afirma ter sido o teatro o primeiro a se organizar no impacto pós-golpe, acabando por "propiciar uma espécie de 'modelo' para a arte de resistência" (MOSTAÇO I982, p. 76). 
"Mais do que nunca é preciso cantar"

\section{Referências bibliográficas}

BADER, Wolfgang (Org.). Brecht no Brasil: experiências e influências. São Paulo: Paz e Terra, I987.

BETTI, Maria Silvia. O teatro de resistência. In: FARIA, João Roberto (Org.). História do teatro brasileiro. São Paulo: Perspectiva, 20I3, v. II.

BOAL, Augusto. Hamlet e o filho do padeiro: memórias imaginadas. Rio de Janeiro: Record, 2000.

COSTA, Armando; PONTES, Paulo; VIANNA FILHO, Oduvaldo. Opinião: texto completo do "Show". Rio de Janeiro: Edições do Val, I965.

CRAVO ALBIN, Ricardo. O livro de ouro da MPB: a história de nossa música popular de sua origem até hoje. Rio de Janeiro: Ediouro, 2003.

DINIZ, André. Almanaque do samba: a história do samba, o que ouvir, o que ler, onde curtir. Rio de Janeiro: Jorge Zahar, 2006.

ENCICLOPÉDIA Itaú Cultural de teatro. Disponível em: www.itaucultural.org.br/teatro/. Acesso em: 23 fev. 20I4.

FARIA, João Roberto (Org.). História do teatro brasileiro. São Paulo: Perspectiva, 20I3, v. II.

GARCIA, Miliandre. Teatro e resistência cultural: o Grupo Opinião. Temáticas, Campinas, n. 37/38, ano I9, 20II.

GUINSBURG, Jacó; FARIA, João Roberto; LIMA, Mariângela Alves de (Org.). Dicionário do teatro brasileiro: temas, formas e conceitos. São Paulo: Perspectiva/ Sesc, 2009.

HOLLANDA, Heloisa Buarque de; GONÇALVES, Marcos Augusto. Cultura e participação nos anos 60. São Paulo: Brasiliense, I982.

KÜHNER, Maria Helena; ROCHA, Helena. Opinião: para ter opinião. Rio de Janeiro: Relume Dumará/Secretaria das Culturas do Rio de Janeiro, 2001 .

MOSTAÇO, Edélcio. Teatro e política: Arena, Oficina, Opinião. Uma interpretação da cultura de esquerda. São Paulo: Proposta, I982.

NAPOLITANO, Marcos. Coração civil: arte, resistência e lutas culturais durante o regime militar. Dissertação (Livre-Docência em História do Brasil Independente). Faculdade de Filosofia, Letras e Giências Humanas, Universidade de São Paulo, São Paulo, 20II.

"Seguindo a canção": engajamento político e indústria cultural na MPB (I959-I969). São Paulo: Annablume/FAPESP, 200 I.

NEVES, João das. Ciclo de palestras sobre o teatro brasileiro. Rio de Janeiro: Inacen, I987. v. 5 .

PARANHOS, Kátia (Org.). História, teatro e política. São Paulo: Boitempo, 2012. 
PAVIS, Patrice. Dicionário de teatro. Trad. de Jacó Guinsburg e Maria Lúcia Pereira. São Paulo: Perspectiva, 2OII.

RANGEL, Flávio; FERNANDES, Millôr. Liberdade liberdade. Rio de Janeiro: Civilização Brasileira, I965.

ROSELL, Mariana. "Mas, afinal, o que é liberdade?": o espetáculo Liberdade liberdade (I965) e a resistência cultural ao regime militar. Cadernos de Clio, Curitiba, n. 4, 20I3, pp. 23I-54.

SCHWARZ, Roberto. Cultura e política: I964-I969. In: O pai de família e outros estudos. Rio de Janeiro: Paz e Terra, I978.

Mariana Rodrigues Rosell - Graduanda em História pela Universidade de São Paulo.

rosell.mariana@gmail.com 